\title{
Practices in peptic ulcer bleeding controversies among university- versus nonuniversity-affiliated gastroenterologists
}

\author{
Justin Cheung MD FRCPC ${ }^{1}$, Grant Sawisky MD², Robert Enns MD FRCPC ${ }^{3}$, \\ Michael F Byrne MB ChB ${ }^{4}$, Qiaohao Zhu PhD ${ }^{5}$, Clarence KW Wong MD FRCPC ${ }^{2}$
}

\begin{abstract}
J Cheung, G Sawisky, R Enns, MF Byrne, Q Zhu, CKW Wong. Practices in peptic ulcer bleeding controversies among universityversus nonuniversity-affiliated gastroenterologists. Can J Gastroenterol 2010;24(4):261-265.
\end{abstract}

BACKGROUND: Practices relating to acute peptic ulcer bleeding (APUB) outside of guideline recommendations are unknown.

OBJECTIVE: To evaluate the practices of university-affiliated (UA) versus nonuniversity-affiliated (non-UA) gastroenterologists in controversial APUB issues.

METHODS: Gastroenterologists in Canada were mailed an anonymous questionnaire (January 2008) regarding APUB management.

RESULTS: Responses were received for 281 of the 530 questionnaires mailed $(53 \%)$. There were no differences between the UA versus non-UA gastroenterologists regarding acid suppression medication and route of administration pre- and postendoscopy (all $\mathrm{P}>0.05$ ). There were no differences in endoscopic practices between groups regarding large versus small volume injection, endoclip versus combination injection plus coagulation, endoclip versus endoclip plus injection, and management of adherent clots (all $\mathrm{P}>0.05$ ). There was variability within each group regarding optimal empirical acid suppression pre-and postendoscopy, volume of injection therapy and endoclip use. The non-UA group had longer delays before restarting acetylsalicylic acid $(\mathrm{P}=0.08)$ and warfarin $(\mathrm{P}=0.02)$ post-APUB.

CONCLUSIONS: UA and non-UA gastroenterologists have similar practices in acid suppression and endoscopic therapy for controversial APUB issues; however, non-UA gastroenterologists appear more cautious in restarting acetylsalicylic acid and warfarin. Further studies are needed to address the optimal empirical acid suppression pre- and postendoscopy, injection therapy volume, endoclip use, and timing of restarting antiplatelet and anticoagulation therapy.

Key Words: Acid suppression; Gastrointestinal endoscopy; Peptic ulcer bleeding; Proton pump inhibitor; Survey

Deptic ulcers are a common cause of nonvariceal upper gastrointestinal bleeding, which is considered to be a medical emergency (1). Evidence-based guideline recommendations on the management of nonvariceal upper gastrointestinal bleeding have been published $(2,3)$. However, there remains several aspects of acute peptic ulcer bleeding (APUB) for which there is limited evidence to guide management. For example, empirical acid suppression while awaiting endoscopy may be efficacious but is only performed selectively. Although

\section{Prise en charge des hémorragies d'ulcères gastroduodénaux entre gastro-entérologues des milieux universitaires et non universitaires}

\begin{abstract}
HISTORIQUE : On ignore quelles sont les pratiques face aux hémorragies d'ulcères gastroduodénaux (HUGD) en dehors des normes recommandées par les lignes directrices.

OBJECTIF : Évaluer les pratiques des gastro-entérologues affiliés ou non affiliés à des $\mathrm{CHU}$ ( $\mathrm{A}-\mathrm{CHU}$, non $\mathrm{A}-\mathrm{CHU})$ pour ce qui est de la prise en charge des HUGD.

MÉTHODES : On a posté aux gastro-entérologues canadiens un questionnaire anonymisé (janvier 2008) au sujet de la prise en charge des HUGD. RÉSULTATS : Sur les 530 questionnaires postés, 281 sont revenus (53\%). On n'a noté aucune différence entre les gastro-entérologues A-CHU et non A-CHU pour ce qui est des médicaments suppresseurs de l'acidité et leur voie d'administration pré- et post-endoscopique (tous $\mathrm{P}>0,05$ ). On n'a noté aucune différence quant aux pratiques endoscopiques entre les groupes en ce qui a trait à l'injection d'un volume important versus faible, la pose d'endoclip versus injection combinée plus coagulation, l'endoclip versus l'endoclip plus injection et la prise en charge des caillots adhérents (tous $\mathrm{P}>0,05$ ). On a noté une variabilité à l'intérieur de chaque groupe en ce qui a trait à la suppression empirique optimale de l'acidité pré- et postendoscopie, au volume du traitement d'injection et à l'emploi de l'endoclip. Le groupe non A-CHU a davantage tardé avant de redébuter l'acide acétylsalicylique $(P=0,08)$ et la warfarine $(P=0,02)$ après HUGD.

CONCLUSION : Les gastro-entérologues A-CHU et non A-CHU emploient les mêmes pratiques pour la suppression acide et le traitement endoscopique dans un tableau d'HUGD. Toutefois, les gastro-entérologues non A-CHU ont semblé plus prudents lors du redémarrage de l'acide acétylsalicylique et de la warfarine. D'autres études s'imposent si l'on veut étudier la suppression empirique optimale, l'acidité pré- ou postendoscopique, le volume du traitement d'injection, l'emploi de l'endoclip et le moment du redémarrage des antiplaquettaires et des anticoagulants.
\end{abstract}

${ }^{1}$ Department of Medicine, Division of Gastroenterology, University of Alberta, University of Alberta Hospital; ${ }^{2}$ Royal Alexandra Hospital, Edmonton, Alberta; ${ }^{3}$ Department of Medicine, Division of Gastroenterology, University of British Columbia, St Paul's Hospital; ${ }^{4}$ Vancouver General Hospital, Vancouver, British Columbia; ${ }^{5}$ Integrated Centre for Care Advancement through Research (iCARE), Edmonton, Alberta Correspondence: Dr Clarence KW Wong, 331 CSC, Royal Alexandra Hospital, 10240 Kingsway Avenue, Edmonton, Alberta.

Telephone 780-735-6838,fax 780-735-6792,e-mail clarence.wong@ualberta.ca

Received for publication April 27, 2009. Accepted May 27, 2009 
TABLE 1

Respondent characteristics

\begin{tabular}{|c|c|c|c|}
\hline & \multicolumn{2}{|c|}{ Gastroenterologist } & \multirow[b]{2}{*}{$\mathbf{P}$} \\
\hline & $\begin{array}{c}\text { University } \\
\text { affiliated } \\
(n=175)\end{array}$ & $\begin{array}{c}\text { Nonuniversity } \\
\text { affiliated } \\
(n=106)\end{array}$ & \\
\hline \multicolumn{4}{|c|}{ Length of practice, years } \\
\hline$<5$ & $40(23)$ & $17(16)$ & 0.38 \\
\hline $5-20$ & $72(41)$ & $49(46)$ & \\
\hline $21-30$ & $41(23)$ & $30(28)$ & \\
\hline$>30$ & $22(13)$ & $10(9)$ & \\
\hline \multicolumn{4}{|c|}{ Gastroenterology fellow training? } \\
\hline Yes & $127(73)$ & $5(5)$ & $<0.001$ \\
\hline No & $48(27)$ & $101(95)$ & \\
\hline \multicolumn{4}{|l|}{ Population serving } \\
\hline$<100,000$ & $4(2)$ & $18(17)$ & $<0.001$ \\
\hline $100,000-500,000$ & $48(27)$ & $62(58)$ & \\
\hline$>500,000$ & $122(70)$ & $26(25)$ & \\
\hline Did not respond & $1(1)$ & $0(0)$ & \\
\hline \multicolumn{4}{|c|}{ Routinely manage acute peptic ulcer bleeding? } \\
\hline Yes & $152(87)$ & $91(86)$ & 0.93 \\
\hline No & $23(13)$ & $14(13)$ & \\
\hline Did not respond & $0(0)$ & $1(1)$ & \\
\hline \multicolumn{4}{|l|}{ Perform endoscopy? } \\
\hline Yes & $174(99.4)$ & $106(100)$ & 0.44 \\
\hline No & $1(0.6)$ & $0(0)$ & \\
\hline
\end{tabular}

Data presented as $n(\%)$ unless indicated otherwise

literature is based on studies from these centres (1). However, it is unknown whether practice in the university teaching and research setting is different from the nonuniversity setting.

The objective of the present study was to evaluate the practices of UA and nonuniversity-affiliated (non-UA) Canadian gastroenterologists regarding APUB issues for which there are no current guidelines.

\section{Subjects}

An anonymous questionnaire on APUB management was mailed to all 530 Canadian gastroenterologists actively registered (at December 2007) with the College of Physicians and Surgeons of Canada in each province and territory. The questionnaires were labelled with computer-generated, confidential identification numbers. The first questionnaires were mailed in January 2008. A second questionnaire was mailed in February 2008 to subjects who did not respond to the initial mailing. The University of Alberta Health Research Ethics Board and the Department of Medicine (Edmonton, Alberta) approved the study.

\section{Survey methods}

The questionnaire included demographic questions on the participant's university versus nonuniversity affiliation, province of practice, population served, length of practice, gastroenterology fellow training involvement and routine endoscopy practice. The questionnaire also evaluated APUB management issues for which there were no specific recommendations based on recent guidelines $(2,3)$. Questions regarding acid suppression, endoscopic therapy, and management of antiplatelet and anticoagulation during APUB were included. The questionnaire was one page, double-sided and took approximately 3 min to complete. Questionnaire responses were entered into a confidential electronic spreadsheet.

\section{Statistics}

Statistical calculations were performed with Stata/IC 10 software (StataCorp, USA). The $\chi^{2}$ squared test was used to compare the categorical data outcomes. A two-tailed $\mathrm{P}<0.05$ was considered to be statistically significant.

\section{RESULTS}

A total of 288 gastroenterologists responded to the survey. Seven were excluded due to incomplete questionnaires. The demographics of the 281 (53\%) respondents included in the study are shown in Table 1 . There were $175 \mathrm{UA}$ and 106 non-UA respondents. UA gastroenterologists were significantly more likely to participate in gastroenterology subspecialty training $(\mathrm{P}<0.001)$ and serve larger populations $(\mathrm{ie}$, greater than 500,000$)$ $(\mathrm{P}<0.001)$. There were no significant differences in the length of practice or the proportion that routinely manage APUB $(\mathrm{P}>0.05$ for all). Only one respondent did not perform endoscopy.

The questions and responses to the questionnaire are shown in Tables 2-4. There were no significant differences in acid suppression management pre-endoscopy (stable and unstable patients), and postendoscopy between UA and non-UA gastroenterologists (all $\mathrm{P}>0.05$ ). Approximately $94 \%$ and $95 \%$, respectively $(\mathrm{P}=0.43)$, of $\mathrm{UA}$ and non-UA gastroenterologists believed that intravenous (IV) pantoprazole infusion therapy was superior to IV $\mathrm{H}_{2}$ blockers. However, only $71 \%$ and $66 \%$ of $\mathrm{UA}$ and non-UA $(\mathrm{P}=0.40)$ gastroenterologists, respectively, believed that IV proton pump inhibitor (PPI) infusion was superior to oral PPI therapy after endoscopy for high-risk stigmata ulcers.

There were no significant differences in practices between UA and non-UA groups for endoscopic therapy issues such as large versus small volume injection therapy, endoclips versus combination injection plus coagulation, endoclip alone versus endoclip plus injection, and management and removal of adherent clots (all $\mathrm{P}>0.05$ ).

There was a trend toward longer delay by non-UA gastroenterologists before starting or continuing acetylsalicylic acid therapy in APUB patients with recent acute myocardial infarctions $(P=0.08)$. Only $22 \%$ of non-UA gastroenterologists would restart acetylsalicylic acid within seven days compared with 37\% of UA gastroenterologists. There was a significant difference in restarting warfarin in patients with high-risk atrial fibrillation. The non-UA group similarly tended to have a longer delay before restarting warfarin ( $24 \%$ within seven days) than the UA group ( $43 \%$ within seven days).

\section{DISCUSSION}

The management of APUB in controversial practices outside of available evidence-based guideline recommendations is unknown $(2,3)$. Additionally, much of the published literature regarding APUB originates from hospitals affiliated with universities. Currently, there is no literature describing the APUB practices of UA compared with non-UA gastroenterologists. The current study surveyed the practices of Canadian gastroenterologists and found that acid suppression and endoscopic practices of UA and non-UA gastroenterologists were similar in 
TABLE 2

Gastroenterologist responses to questions regarding acute peptic ulcer bleeding (APUB) and acid suppression

\begin{tabular}{|c|c|c|c|}
\hline & \multicolumn{2}{|c|}{ Gastroenterologist } & \multirow[b]{2}{*}{$\mathbf{P}$} \\
\hline & University affiliated $(n=175)$ & Nonuniversity affiliated $(n=106)$ & \\
\hline PPI IV continuous infusion & $88(50)$ & $57(54)$ & \multirow[t]{4}{*}{0.55} \\
\hline PPI IV OD or BID & $30(17)$ & $14(13)$ & \\
\hline $\mathrm{H}_{2}$ antagonist IV & $6(3)$ & $4(4)$ & \\
\hline No answer & $8(5)$ & $1(1)$ & \\
\hline PPI IV continuous infusion & $166(95)$ & $100(94)$ & \multirow[t]{5}{*}{0.09} \\
\hline PPI oral OD or BID & $0(0)$ & $4(4)$ & \\
\hline PPI IV OD or BID & $5(3)$ & $1(1)$ & \\
\hline $\mathrm{H}_{2}$ antagonist IV & $1(0.5)$ & $0(0)$ & \\
\hline No answer & $3(2)$ & $1(1)$ & \\
\hline \multicolumn{4}{|c|}{ Q3. Which do you routinely use postendoscopy to treat patients with APUB with high-risk stigmata (spurting, visible vessel, oozing or clots)? } \\
\hline No answer & $0(0)$ & $0(0)$ & 0.19 \\
\hline \multicolumn{4}{|c|}{$\begin{array}{l}\text { Q4. Do you believe IV PPI infusion is definitely superior to oral PPI postendoscopic therapy for APUB with high-risk stigmata } \\
\text { (spurting, visible vessel, oozing or clots)? }\end{array}$} \\
\hline Yes & $125(71)$ & $70(66)$ & \multirow[t]{4}{*}{0.40} \\
\hline No & $11(6)$ & $7(7)$ & \\
\hline Likely equivalent & $15(9)$ & $16(15)$ & \\
\hline Unsure & $24(14)$ & $13(12)$ & \\
\hline \multicolumn{4}{|c|}{$\begin{array}{l}\text { Q5. Do you believe IV pantoprazole infusion is definitely superior to IV } \mathrm{H}_{2} \text { blockers postendoscopic therapy for APUB with } \\
\text { high-risk stigmata (spurting, visible vessel, oozing or clots)? }\end{array}$} \\
\hline Yes & $165(94)$ & $101(95)$ & \multirow[t]{2}{*}{0.43} \\
\hline No & $4(2)$ & $0(0)$ & \\
\hline
\end{tabular}

Data presented as $n(\%)$ unless indicated otherwise. BID Twice daily; IV Intravenous; OD Once daily; PPI Proton pump inhibitor

TABLE 3

Gastroenterologist responses to questions regarding acute peptic ulcer bleeding (APUB) and endoscopic therapy

\begin{tabular}{|c|c|c|c|}
\hline & \multicolumn{2}{|c|}{ Gastroenterologist } & \multirow[b]{2}{*}{$\mathbf{P}$} \\
\hline & University affiliated $(n=175)$ & Nonuniversity affiliated $(n=106)$ & \\
\hline \multicolumn{4}{|c|}{$\begin{array}{l}\text { Q6. Do you believe large volume injection therapy }(\geq 10 \mathrm{~mL} \text { ) is routinely better than small volume injection (<10 } \mathrm{mL} \text { ) for high risk APUB } \\
\text { (either adrenaline } 1: 10,000 \text { or saline)? }\end{array}$} \\
\hline No & $97(55)$ & $57(54)$ & \\
\hline \multicolumn{4}{|c|}{$\begin{array}{l}\text { Q7. Given that combination injection and coagulation endoscopic therapy has demonstrated efficacy, do you believe that endoclips are even more } \\
\text { efficacious for high-risk bleeding ulcers? }\end{array}$} \\
\hline Yes for select lesions & $52(30)$ & $38(36)$ & \\
\hline No for most lesions & $69(39)$ & $38(36)$ & \\
\hline Unsure & $44(25)$ & $20(19)$ & \\
\hline \multicolumn{4}{|c|}{ Q8. Do you believe that combination of endoclips plus injection therapy is superior to endoclips alone? } \\
\hline Yes for most lesions & $64(37)$ & $27(25)$ & 0.19 \\
\hline Yes for select lesions & $23(13)$ & $18(17)$ & \\
\hline Endoscopic therapy without removal & $21(12)$ & $11(10)$ & \\
\hline No endoscopic therapy - fear of inducing bleeding & $2(1)$ & $3(3)$ & \\
\hline $\begin{array}{l}\text { No endoscopic therapy - would not change subsequent } \\
\text { management }\end{array}$ & $3(2)$ & $1(1)$ & \\
\hline
\end{tabular}

Data presented as $n(\%)$ unless indicated otherwise 
TABLE 4

Gastroenterologist responses to questions regarding acute peptic ulcer bleeding and restarting acetylsalicylic acid or warfarin

\begin{tabular}{|c|c|c|c|}
\hline & \multicolumn{2}{|c|}{ Gastroenterologist } & \multirow[b]{2}{*}{$\mathbf{P}$} \\
\hline & $\begin{array}{c}\text { University } \\
\text { affiliated }(n=175)\end{array}$ & $\begin{array}{c}\text { Nonuniversity } \\
\text { affiliated }(n=106)\end{array}$ & \\
\hline \multicolumn{4}{|c|}{$\begin{array}{l}\text { Q11. When would you recommend starting or continuing } \\
\text { acetylsalicylic acid in a patient with a recent stable acute } \\
\text { myocardial infarction, who has been successfully treated } \\
\text { endoscopically for an ulcer with stigmata? }\end{array}$} \\
\hline$<1$ day & $8(5)$ & $0(0)$ & 0.08 \\
\hline $1-3$ days & $12(7)$ & $3(3)$ & \\
\hline 3-7 days & $45(26)$ & $20(19)$ & \\
\hline $1-2$ weeks & $49(28)$ & $31(29)$ & \\
\hline $2-4$ weeks & $23(13)$ & $18(17)$ & \\
\hline$>4$ weeks & $15(9)$ & $10(10)$ & \\
\hline $\begin{array}{l}\text { Routinely repeat } \\
\text { endoscopy before } \\
\text { restarting }\end{array}$ & $22(13)$ & $21(20)$ & \\
\hline No answer & $1(0.6)$ & $3(3)$ & \\
\hline \multicolumn{4}{|c|}{$\begin{array}{l}\text { Q12. When would you recommend starting or continuing warfarin } \\
\text { in a patient with high-risk atrial fibrillation, who has been } \\
\text { successfully treated endoscopically for an ulcer with stigmata } \\
\text { (ie, visible vessel, oozing or clot)? }\end{array}$} \\
\hline$<1$ day & $2(1)$ & $0(0)$ & 0.02 \\
\hline $1-3$ days & $14(8)$ & $8(8)$ & \\
\hline 3-7 days & $59(34)$ & $17(16)$ & \\
\hline $1-2$ weeks & $36(21)$ & $32(30)$ & \\
\hline $2-4$ weeks & $2(13)$ & $13(12)$ & \\
\hline$>4$ weeks & $12(7)$ & $7(7)$ & \\
\hline $\begin{array}{l}\text { Routinely repeat } \\
\text { endoscopy before } \\
\text { restarting }\end{array}$ & $29(17)$ & $28(26)$ & \\
\hline No answer & $0(0)$ & $1(1)$ & \\
\hline
\end{tabular}

Data presented as $n(\%)$ unless indicated otherwise

several areas for which evidence-based recommendations are not available.

Pre-endoscopy acid suppression practices between UA and non-UA gastroenterologists were comparable. Recent APUB guidelines have recommended the empirical use of high-dose PPIs while awaiting endoscopy $(2,3)$. However, the guidelines noted that there was insufficient evidence to recommend a preferred route of administration. Recent evidence suggests that the empirical use of PPI therapy pre-endoscopy reduces the need for endoscopic therapy, although outcomes were not significantly different (4). The current study found that the majority of both UA (95\%) and non-UA gastroenterologists (94\%) manage unstable potential APUB patients with IV PPI therapy while awaiting endoscopy, suggesting a perception that IV administration was preferable for more critical patient groups. For patients presenting with stable potential APUB, there was no difference in acid suppression practice between UA and non-UA groups, but there was similar variability with most (greater than 50\%) using IV PPI infusion and approximately $40 \%$ using intermittent oral or IV PPI. The variability in administration route and PPI dose among stable patients suggest that further studies are required to determine the optimal regimen of empirical PPI pre-endoscopy.
Postendoscopy acid suppression practices were similar between UA and non-UA gastroenterologists. Although highdose IV PPI infusion has been shown to be effective in the prevention of rebleeding from high-risk stigmata (5), it is unknown whether intermittent IV PPI or oral PPI are as effective (6-8). In the current study, the majority of gastroenterologists in both groups recommended IV PPI infusion postendoscopy for lesions with high-risk stigmata. However, not all UA and non-UA gastroenterologists believed that IV PPI infusion was definitely superior to oral PPI postendoscopy (71\% and 66\%, respectively). This may suggest that although IV PPI infusion is currently the treatment of choice, there are many gastroenterologists who are unsure or believe that further evidence is required to determine the efficacy of oral PPI. Both groups believed that IV PPI infusion was superior to IV $\mathrm{H}_{2}$ blockers, which is consistent with recent evidence $(9,10)$.

There was variability in several areas of endoscopic practice with respect to APUB for which guidelines have not yet been established, such as the volume of injection therapy and endoclip use. However, the variability in responses was similar between UA and non-UA gastroenterologists. The optimal volume or limits of injection therapy are unknown. Large volume injection therapy may be more effective than small volume injection therapy for preventing recurrent bleeding (11). Both UA and nonUA gastroenterologists appeared evenly divided over the benefit of large volume injection. The use of endoclips is considered to be a promising endoscopic tool for APUB (3). However, the efficacy of endoclips compared with traditional injection and coagulation therapy has been variable (12), and both UA and non-UA groups varied in their opinions of endoclip efficacy. Additionally, there was similar variability in the opinion that injection plus endoclip therapy is superior to endoclips alone. Overall, there was uncertainty in the areas of optimal volume of injection therapy and the use of endoclips, which may represent a spectrum of personal comfort level of endoscopists with the techniques. The wide variability of practices in these areas suggest that further studies and guidelines are needed.

The optimal endoscopic management of adherent clots is considered to be controversial $(13,14)$. Endoscopic removal of adherent clots to visualize the underlying lesion may be of concern for causing further uncontrolled bleeding. However, the majority (85\%) of both UA and non-UA endoscopists recommended removal of an adherent clot to assess and treat the underlying lesion. There were similar practices between both groups and most used a combination of injection therapy with mechanical removal. This suggests minimal discrepancy among gastroenterologists in the endoscopic management of adherent clots.

There is no available evidence to guide the timing of reinstitution of antiplatelet or anticoagulation therapy in patients with APUB. Acetylsalicylic acid is a recommended treatment in patients with acute myocardial infarction but is also a known ulcerogenic agent (15). There was a trend toward longer delay before acetylsalicylic acid reinstitution among non-UA gastroenterologists. Only 22\% of the non-UA group, compared with $37 \%$ of UA group, would start acetylsalicylic acid within one week of APUB. In terms of restarting warfarin for patients with high-risk atrial fibrillation and APUB, there was a significant difference between the UA and non-UA gastroenterologists. There was a longer delay before restarting 
warfarin in the non-UA group, with $24 \%$ recommending warfarin within one week compared with $43 \%$ in the UA group. Possible reasons for the differences in the management of antiplatelet and anticoagulation management include differential access to emergency endoscopy and surgical back-up in cases of APUB rebleeding.

One of the potential limitations of the present study is the division of gastroenterologists by university affiliation to indicate a practice involved in teaching and research. However, an alternative division by community versus academic practice would be potentially less accurate because a community practice does not necessarily exclude involvement in research and training. An additional limitation is that the study did not survey the APUB practices for which guidelines exist. However, we would expect that these less controversial practices would be less variable among gastroenterologists because guidelines were published several years earlier $(2,3)$.

\section{CONCLUSION}

There are similar practices in acid suppression and endoscopic therapy among UA and non-UA gastroenterologists in controversial areas for which evidence-based APUB guideline recommendations are not available. However, non-UA gastroenterologists were more cautious with restarting acetylsalicylic acid and warfarin. Additionally, controversy still exists regarding optimal empirical acid suppression pre- and postAPUB, volume of injection therapy and the use of endoclips. Future studies and guidelines addressing optimal acid suppression therapy, injection volume, endoclip therapy, and the timing of restarting antiplatelet and anticoagulation agents are needed to guide physicians more effectively.

DISCLOSURE: The authors have no potential conflicts of interest or financial arrangements to declare.

\section{REFERENCES}

1. Barkun A, Sabbah S, Enns R, et al. The Canadian Registry on Nonvariceal Upper Gastrointestinal Bleeding and Endoscopy (RUGBE): Endoscopic hemostasis and proton pump inhibition are associated with improved outcomes in a real-life setting. Am J Gastroenterol 2004;99:1238-46.

2. Barkun A, Fallone CA, Chiba N, et al. A Canadian clinical practice algorithm for the management of patients with nonvariceal upper gastrointestinal bleeding. Can J Gastroenterol 2004;18:605-9.
3. Barkun A, Bardou M, Marshall JK. Consensus recommendations for managing patients with nonvariceal upper gastrointestinal bleeding. Ann Intern Med 2003;139:843-57.

4. Lau JY, Leung WK, Wu JC, et al. Omeprazole before endoscopy in patients with gastrointestinal bleeding. $\mathrm{N}$ Engl J Med 2007:356:1631-40.

5. Lau JY, Sung JJ, Lee KK, et al. Effect of intravenous omeprazole on recurrent bleeding after endoscopic treatment of bleeding peptic ulcers. N Engl J Med 2000;343:310-6.

6. Khuroo MS, Yattoo GN, Javid G, et al. A comparison of omeprazole and placebo for bleeding peptic ulcer. N Engl J Med 1997;336:1054-8.

7. Javid G, Masoodi I, Zargar SA, et al. Omeprazole as adjuvant therapy to endoscopic combination injection sclerotherapy for treating bleeding peptic ulcer. Am J Med 2001;111:280-4 .

8. Murthy S, Keyvani L, Leeson S, Targownik LE. Intravenous versus high-dose oral proton pump inhibitor therapy after endoscopic hemostasis of high-risk lesions in patients with acute nonvariceal upper gastrointestinal bleeding. Dig Dis Sci 2007;52:1685-90.

9. van Rensburg C, Barkun AN, Racz I, et al. Clinical trial: Intravenous pantoprazole vs. ranitidine for the prevention of peptic ulcer rebleeding: A multicentre, multinational, randomized trial. Aliment Pharmacol Ther 2009;29:497-507.

10. Jensen DM, Pace SC, Soffer E, Comer GM. Continuous infusion of pantoprazole versus ranitidine for prevention of ulcer rebleeding: A U.S. multicenter randomized, double-blind study. Am J Gastroenterol 2006;101:1991-9; quiz 2170.

11. Lin HJ, Hsieh YH, Tseng GY, Perng CL, Chang FY, Lee SD. A prospective, randomized trial of large- versus small-volume endoscopic injection of epinephrine for peptic ulcer bleeding. Gastrointest Endosc 2002;55:615-9.

12. Sung JJ, Tsoi KK, Lai LH, Wu JC, Lau JY. Endoscopic clipping versus injection and thermo-coagulation in the treatment of non-variceal upper gastrointestinal bleeding: A meta-analysis. Gut 2007;56:1364-73.

13. Jensen DM, Kovacs TO, Jutabha R, et al. Randomized trial of medical or endoscopic therapy to prevent recurrent ulcer hemorrhage in patients with adherent clots. Gastroenterology 2002;123:407-13.

14. Bleau BL, Gostout CJ, Sherman KE, et al. Recurrent bleeding from peptic ulcer associated with adherent clot: A randomized study comparing endoscopic treatment with medical therapy. Gastrointest Endosc 2002;56:1-6.

15. Anderson JL, Adams CD, Antman EM, et al. ACC/AHA 2007 guidelines for the management of patients with unstable angina/ non-ST-elevation myocardial infarction: A report of the American College of Cardiology/American Heart Association Task Force on Practice Guidelines (Writing committee to revise the 2002 guidelines for the management of patients with unstable angina/ non-ST-elevation myocardial infarction) developed in collaboration with the American College of Emergency Physicians, the Society for Cardiovascular Angiography and Interventions, and the Society of Thoracic Surgeons endorsed by the American Association of Cardiovascular and Pulmonary Rehabilitation and the Society for Academic Emergency Medicine. J Am Coll Cardiol 2007;50:e1-e157. 


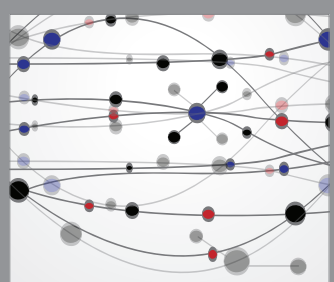

The Scientific World Journal
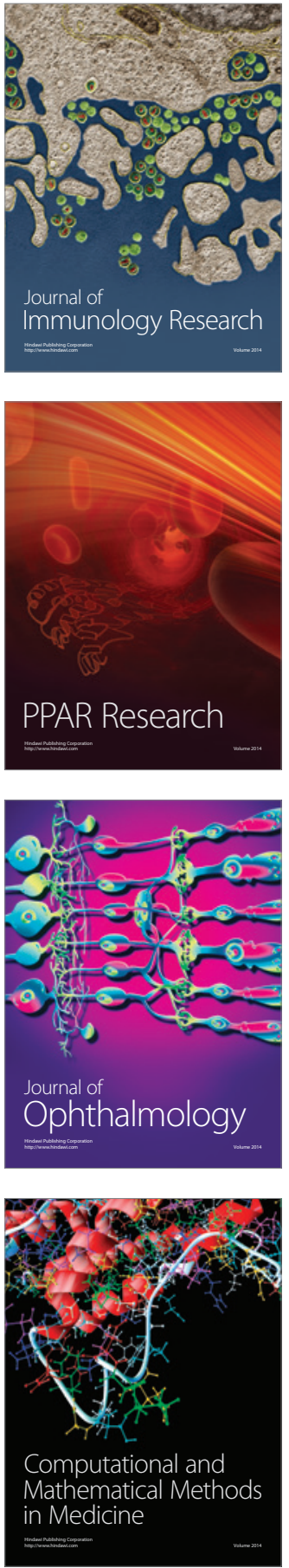

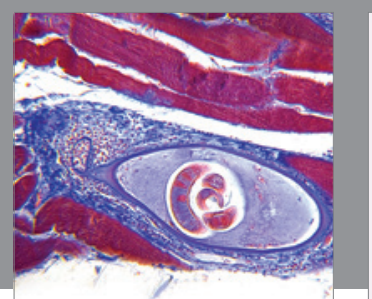

Gastroenterology Research and Practice

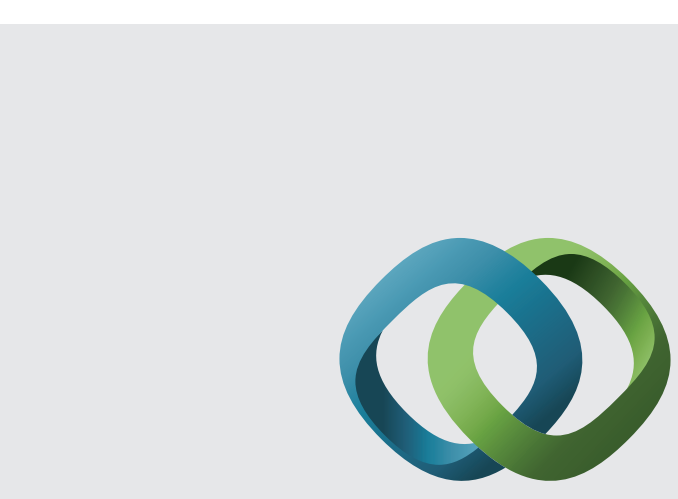

\section{Hindawi}

Submit your manuscripts at

http://www.hindawi.com
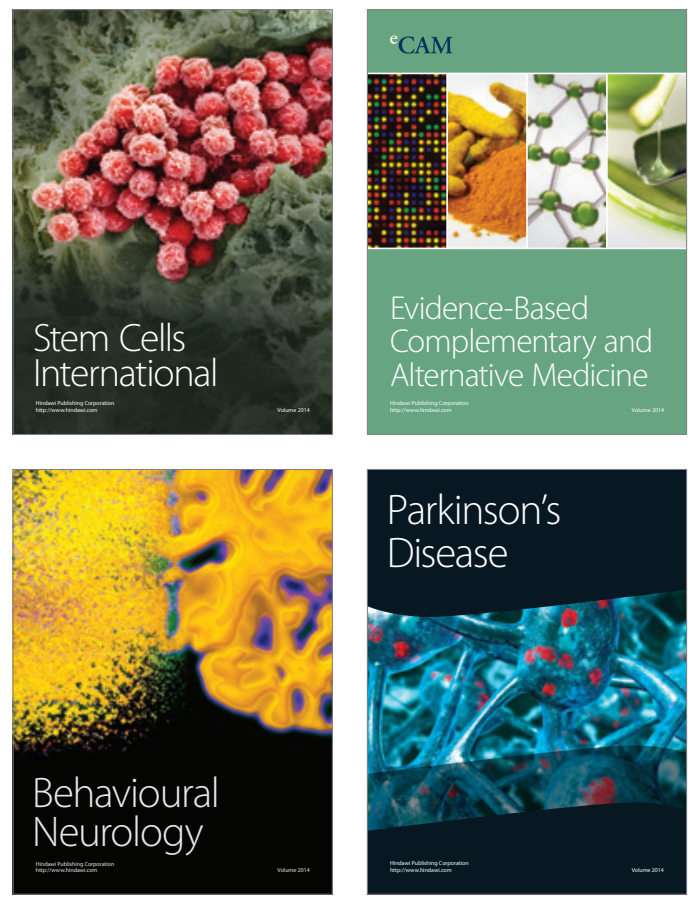
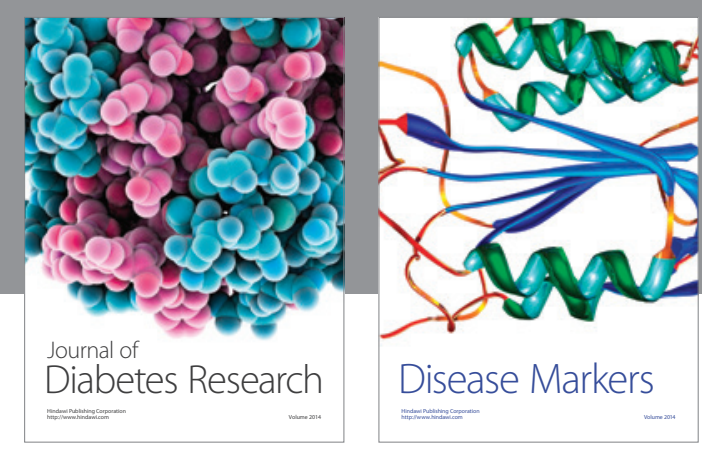

Disease Markers
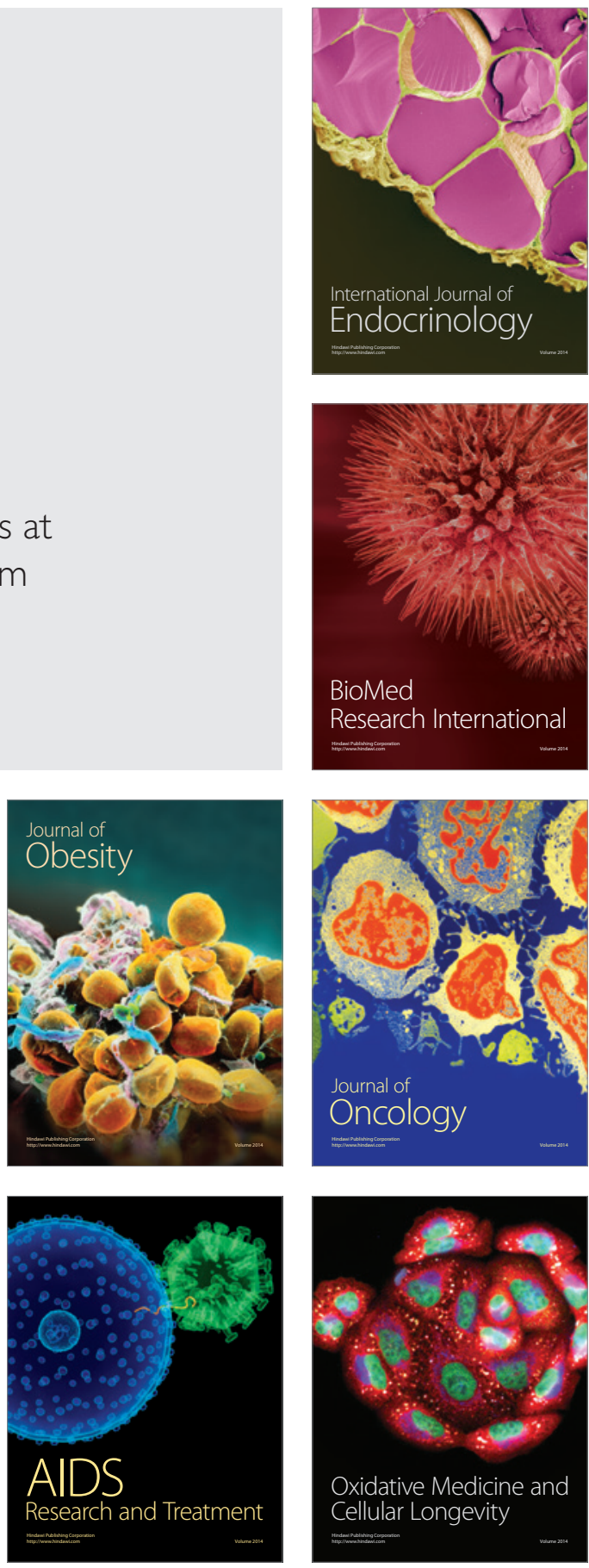